manufacturers can supply their needs. A policy of 'Sell British Goods' is at least as important as 'Buy British Goods', if for no other reason than the difficulties at present encountered by customers wishing to purchase British goods-difficulties which, in some cases at any rate, are due to the obvious reluctance or indifference of the retailer to sell British goods.

The British Industries Fair is the direct outcome of the measures taken by the Commercial Intelligence Branch of the Board of Trade, immediately after the outbreak of War in 1914, to deal with the situation which had arisen in many industries owing to the cessation of trade with enemy countries. From the first Fair, which was held in May 1915, in the Royal Agricultural Hall, London, with an exhibitors' floor space of 80,000 square feet, the size of the Fair has steadily developed; the Birmingham Section was started in 1920, and in the 1929 London Fair the area occupied by exhibits was more than 310,000 square feet. Since 1926 the Treasury has made a grant of $£ 25,000$ per annum for advertising purposes, but the Committee reports that it received overwhelming evidence that this sum was totally inadequate for effective world publicity, and recommends that the Government should establish a regular annual publicity grant of a minimum of $£ 100,000$ and recognise the Fair as an integral feature of British economic policy. The Committee agrees with the view that advertisement of the Fair abroad is of value to British industry generally, and records its conviction that expenditure of this character, by assisting the restoration of prosperity to British industry, will prove to be a national economy and be amply justified by results. The preponderance of evidence was emphatically against increasing charges for space as a contribution towards advertising expenses; and regarding the Fair as a means of expand. ing British industry, the Committee urges that the recommended national contribution is insignificant compared to the present expenditure on unproductive relief of unemployment which it is designed to reduce.

Other recommendations include the acquisition of a site easily accessible from central London, and its equipment with buildings capable of extension as required; the continuance and, if possible, supplementing of the Government banquet to celebrate the opening of the Fair; the establishing of a special Committee to direct the expenditure of the publicity. grant, the administration of which and the management of the London Section should remain under the control of the Department of Overseas Trade; some extension of the hours of admission of the public to the London Section, stricter exclusion of the general public during the hours reserved for trade buyers, and an extension of the free passport visa granted to foreign buyers attending the Fair to cover at least three months and return visits to Great Britain during that time.

\title{
Lattice Distortion and the Hardening of Metals.
}

T $T$ has hitherto been regarded almost as axiomatic that lattice distortion of a metal will result in hardening. Doubt of the universality of such a work done by W. L. Fink and K. R. van Horn, which

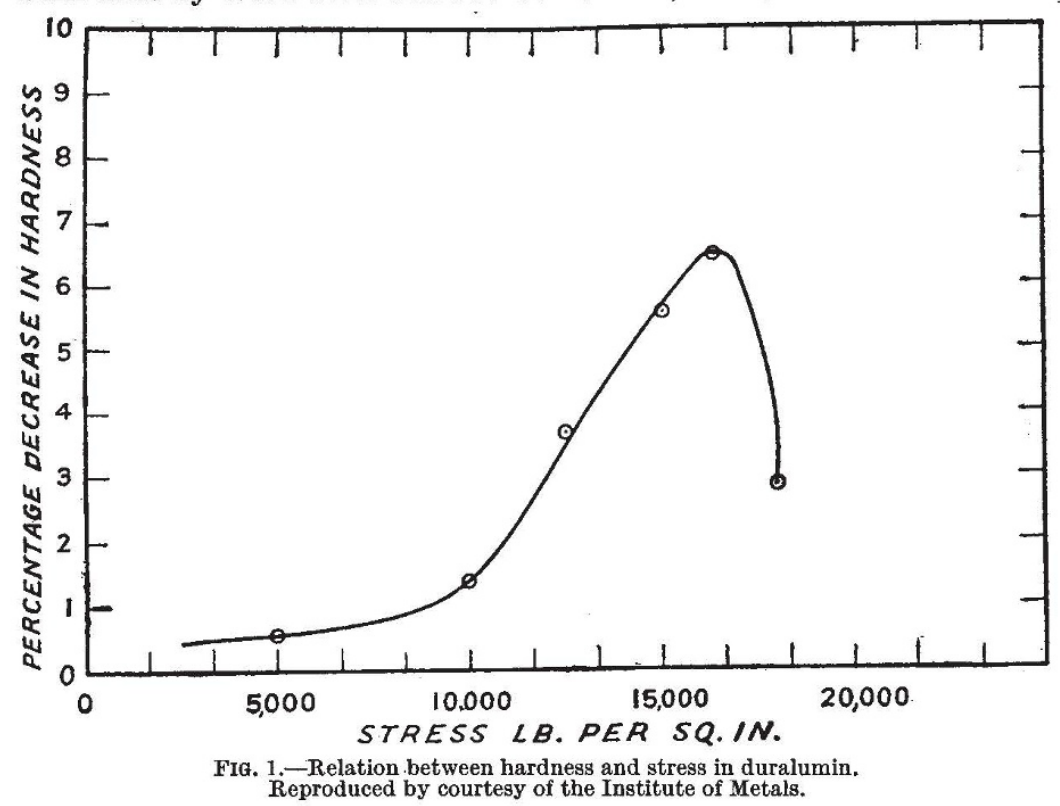
hypothesis is now justified, however, as the result of

$X$-ray examination was made simultaneously, and the effacement of the $K a$ doublet, the diffuseness or elongation of the reflection images, and the widening of the diffraction rings, proved that lattice distortion had in fact been produced.

In Fig. 1 the changes in hardness for the duralumin specimen are shown in relation to the stress set up. The material is at first softened and not hardened, the softening increasing with the stress up to the elastic limit. At stresses higher than this, the hardening resulting from the plastic deformation counteracts the softening effect and hardening commences. An exactly similar result was given by the work on the brass, which softened even more than did the aluminium alloy.

It is clear, then, that lattice distortion resulting from elastic deformation can be accompanied by an appreciable decrease in hardness. As the authors point out, however, it is conceivable that where lattice distortion is of a very local character, it may have the opposite effect and harden the material.

In corroboration of the results which have been obtained, the authors cite measurements made

formed the subject of a paper read on Sept. 10 before the Institute of Metals at its annual autumn meeting at Southampton.

The experiments recorded consisted in elastically deforming samples of $70: 30$ brass and duralumin by bending and, whilst still under stress, in measuring the hardness by the Rockwell apparatus on scale ' $\mathrm{E}$ '. by Gayler and Preston on the aluminium alloy with
4.5 per cent of copper and by Chartkoff and Sykes on iron alloyed with 25 per cent of tungsten. In the former case, a specimen quenched from $500^{\circ} \mathrm{C}$. and then aged first at room temperature and then for 3 hours at $200^{\circ}$ C., which showed maximum lattice distortion, had a Brinell hardness number of $\mathbf{5 7}$.

No. 3191, VoL. 126] 
The same specimen after an additional 21 hours at $200^{\circ} \mathrm{C}$. had reached a maximum hardness of 78 but with considerably reduced distortion. The irontungsten alloy, which had been quenched from $1520^{\circ} \mathrm{C}$., had a Rockwell ' $\mathrm{C}$ ' hardness of 14 and pronounced lattice distortion. This alloy after a subsequent ageing for 40 hours at $800^{\circ} \mathrm{C}$. was relatively free from strain but the hardness had risen to 39 .

It would appear, then, that lattice distortion resulting from the precipitation of a new phase will, in some cases at least, reach a maximum and then partially disappear before the stage of greatest mechanical hardness has been attained.

F. C. T.

\section{University and Educational Intelligence.}

THE eighteenth election to Beit Fellowships for Scientific Research, which are of the annual value of $£ 250$ and tenable at the Imperial College of Science and Technology, will take place on or about July 14 next. Not more than three fellowships will be awarded. Candidates must be less than twenty-five years of age at the time of election. Applications must be received by April 14. Particulars can be obtained, by letter only, from the Rector, Imperial College, South Kensington, London, S.W.

TaE following scholarships will be offered for competition by the Institution of Naval Architects in 1931: Naval Architecture-Elgar Scholarship (£130 per ann. for 3 years) and the Vickers-Armstrong Scholarship ( $£ 150$ per ann. for 3 years). Marine Engineering-Parsons Scholarship (£150 per ann. for 3 years) and the Denny Scholarship ( $£ 75$ per ann. for 4 years). The Denny Scholarship is open to boys less than nineteen years of age who have not yet begun their apprenticeship, and is tenable at the University of Glasgow. The remaining scholarships are open to apprentices between the ages of eighteen and twentythree, and are tenable at the Royal Naval College, Greenwich; University of Glasgow; Armstrong College ; University of Liverpool ; and the City and Guilds (Engineering) College. Particulars can be obtained from the Secretary of the Institution of Naval Architects, 2 Adam Street, Adelphi, London, W.C.2.

The Meldola Medal (the gift of the Society of Maccabæans) is awarded annually to the chemist whose published chemical work shows the most promise and is brought to the notice of the administrators during the year ending Dec. 31 prior to the award. The recipient must be a British subject, not more than thirty years of age at the time of the completion of the work. The medal may not be awarded more than once to the same person. In awarding the medal for 1930 the adjudicators will, unless exceptional circumstances arise, give special consideration to work in inorganic or physical chemistry. The next award will be made in January, 1931. The medal is awarded on the advice of the board of examiners of the Institute of Chemistry sitting with representatives of the Society of Maccabæans. Communications should be addressed to the Registrar of the Institute of Chemistry, 30 Russell Square, London, W.C.I.

THE Commonwealth Fund of New York City, supported by gifts from the late Mrs. Stephen V. Harkness, has established for British graduate students a number of fellowships tenable at American universities. The fellowships are normally tenable for two years and are of the annual value of about $£ 600$. Thirty fellowships are available to graduates, either men or women, who are unmarried and not more than thirty years of age on Sept. 1; and ten are available to colonial graduates who have studied at a university in the British Isles and to graduates holding an appointment overseas under the British Government, the Government of India, or the Government of a British Dominion, Colony, Protectorate, or Mandated Territory. Candidates are required to produce evidence of proficiency in some recognised branch of university learning, and must also submit a definite scheme of research or study proposed to be carried out during their residence in the university to which they may be assigned. Applications must be forwarded through the authorities of the candidate's college or university and must reach the Secretary to the Committee, Mr. R. H. Simpson, 35 Portman Square, London, W.I, by Feb. 9, 1931, at latest. In 1930 the number of entries for ordinary and Dominion fellowships was 128 (104 men and 24 women); 35 candidates entered for the Service fellowships and three were appointed. Of the 32 fellows appointed, 20 came from the Faculty of Science and 12 belonged to the group of arts subjects.

\section{Historic Natural Events.}

Dec. 28, 1879. The Tay Bridge Storm.-On the evening and night of Dec. 28 a deep barometric depression passed along the north-west and north coasts of Scotland, moving north-eastwards. Violent gales from west and south-west were experienced over Scotland, the velocity reaching 88 miles per hour at Glasgow from 7.15 to 7.18 P.M. The storm is memorable for the destruction of the Tay Bridge at Dundee. The central raised portion of the bridge, 1050 yards long, broke away and at 7.30 P.M. a train and 75 persons, not one of whom was saved, plunged into the river. It seems probable that the bridge actually fell while the train was crossing. The wind at the time was blowing from west-south-west, almost directly across the bridge, and a continuous stream of sparks came from the wheels as the train passed across, caused probably by the force with which they were pressed against the lee rails. The bridge had only been opened to traffic on June 1, 1878 ; its rapid destruction showed that insufficient allowance had been made for the pressure of the wind, and led to a number of detailed studies on this subject.

Dec. 28, I908. Messina Earthquake.--The earthquake was very destructive within an area of less than 200 square miles. It is estimated that 75,000 persons (about half the total population) were killed in Messina, and 25,000 in Reggio and other places in Calabria. Less than ten minutes after the earthquake, both shores of the straits were swept by sea waves, which reached a height of $35 \mathrm{ft}$. on the Calabrian and $28 \mathrm{ft}$. on the Sicilian coast. A new series of levels made soon after the earthquake showed that both coasts had subsided, the Calabrian coast by 24 inches and the other by 28 inches.

Dec. 28-29, I9I4. Gale off Dutch Coast.-One of the most violent gales of recent years struck the coast of Holland on the night of Dec. 28-29, 1914, after a very stormy month. On the morning of Dec. 29 the wind velocity at the Hook of Holland reached 94 miles per hour, and great damage was done to shipping. The gale was notable also for its long duration and great extent.

Dec. 30, 1788 . Severe Cold in France.-It is recorded in the register of the Canton of La Châtre, Department of l'Indre, that "the frosts have been so severe this year in the month of December that the barometers (sic) have fallen two degrees lowet than in 1709, especially Dec. 30 . The snows covered the ground for more than six weeks."

No. 3191, VoL. 126] 